\title{
Program Intervensi Musik terhadap Hiperaktivitas Anak Attention Deficit Hyperactivity Disorder (ADHD)
}

\author{
Bestari Nindya Suyanto ${ }^{1}$ \& Supra Wimbarti ${ }^{2}$ \\ Fakultas Psikologi Universitas Gadjah Mada
}

\begin{abstract}
Children with hyperactivity subtype of ADHD have difficulty to control their behavior, therefore early intervention is needed by providing therapy specifically designed for children with ADHD. The music intervention program was structured to reduce hyperactivity in children with ADHD. The method of this study was single case experimental design, the study did not have a control group. The participant in this study was a child with hyperactivity subtype of ADHD who never received music therapy. The measurement of hyperactive behavior was done using behavioral checklist. Data was analyzed using interobserver by visual inspection. The results of this study was music intervention could reduce hyperactive behavior in this participants. The reliability of measurements (IOA) were in the range of $80 \%-100 \%$, meaning that there was a level of trust in consistency of the assessment between observers in the good category.
\end{abstract}

Keywords: ADHD; hyperactive behavior; music intervention program; single case experimental design

\begin{abstract}
Abstrak. Tujuan dari penelitian yaitu untuk mengetahui pengaruh dari pemberian intervensi musik terhadap perilaku hiperaktif anak ADHD (Attention-Deficit Hyperactive Disorder) di mana perubahan tersebut dapat diamati melalui penurunan perilaku hyperactive. Program intervensi musik disusun sebagai upaya menurunkan perilaku hiperaktif pada anak ADHD. Metode penelitian single case experimental design, yaitu penelitian yang tidak memiliki kelom pok kontrol. Partisipan dalam penelitian ini adalah anak ADHD subtipe hiperaktif dan belum mendapatkan terapi musik. Pengukuran perilaku hiperaktif dengan menggunakan behavioral checklist. Analisis data akan dilakukan dengan menggunakan inter-observer. Analisis data dengan visual inspection. Hasil penelitian ini menyatakan bahwa pemberian intervensi musik dapat menurunkan perilaku hiperaktif pada partisipan dengan rata-rata IOA (interobserver of agreement) 89\%. Reliabilitas pengukuran (nilai IOA) dalam penelitian ini yaitu dalam rentang $80 \%-100 \%$, artinya ada tingkat kepercayaan terhadap keajegan dari penilaian antar observer berada pada kategori baik.
\end{abstract}

Kata kunci : ADHD; perilaku hiperaktif; program intervensi musik; single case experimental design

American Psychiatric Association (APA) (2013) dalam Diagnostic and Statistical
Manual of Mental Disorder edisi ke-5 (DSM-5) mendefinisikan Attention Deficit

\footnotetext{
${ }^{1}$ Korespondensi mengenai isi artikel ini dapat

dilakukan melalui mbesnindy@gmail.com

2 atau melalui supra@ugm.ac.id 
Hyperactivity Disorder (ADHD) adalah gangguan fungsi perkembangan saraf dengan gejala berupa ketidakmampuan memusatkan perhatian, hiperaktivitas dan impulsivitas yang tidak sesuai dengan usia perkembangan. Prevalensi ADHD pada anak usia sekolah di Indonesia secara umum belum dapat diketahui secara pasti. Prevalensi anak dengan ADHD yang berada di Provinsi Daerah Istimewa Yogyakarta pada tahun 2011 sampai dengan 2016. Pada tahun 2011 sebesar 3,5\% siswa sekolah dasar di Kecamatan Banguntapan Kabupaten Bantul (Rusmawati \& Dewi, 2011), 7,48\% siswa sekolah dasar kelas 1 sampai dengan kelas 3 yang berada di Kecamatan Cangkringan Kabupaten Sleman (Christina, 2012), dan 5,47\% anak ADHD pada usia sekolah di Kota Yogyakarta (Hayati, 2014). Adapun berdasarkan penelitian terbaru pada tahun 2016, terdapat 8,09\% anak dengan ADHD yang berada di Kota Yogyakarta dan Kabupaten Sleman (Wimbarti, Dewi, \& Khoirot dalam Rahmi \& Wimbarti, 2018).

Anak dengan gangguan ADHD, biasanya memiliki komorbid dengan gangguan lainnya. Komorbiditas yang paling sering terjadi antara ADHD dengan dua gangguan lainnya dalam DSM-5 (APA, 2013) yaitu ODD (Oppositional Defiant Disorder) dan CD (Conduct Disorder). Dalam sebuah penelitian, terdapat prosentase $44 \%$ anak dengan ADHD yang memiliki setidaknya satu gangguan lain, 32\% anak ADHD yang memiliki dua gangguan lain, dan $11 \%$ anak ADHD setidaknya memiliki minimal tiga gangguan lainnya (Szatmari, Offord, \& Boyle, 1989; Barkley, 2006). ADHD di masa kanak-kanak mungkin merupakan faktor risiko untuk CD/ODD pada masa remaja (Lee, 2005). Studi tambahan juga menunjukkan bahwa anak dengan ADHD memiliki kesulitan utama dalam mengikuti peraturan atau menunjukkan penurunan perilaku terhadap aturan dalam mengerjakan tugas (Barkley, 2006). Hal tersebut disebabkan karena faktor neurofisiologis, yakni fungsi kerja otak yang kurang optimal pada bagian lobus frontal khususnya pada korteks prefontal sehingga menyebabkan masalah dalam melakukan atensi (fungsi kognitif), pengendalian, serta koordinasi gerak tubuh (fungsi motorik) (Barkley, 2006). Pernyataan tersebut diperkuat oleh hasil penelitian yang dilakukan Lalusu, Kaunang, dan Kandou (2014) memaparkan bahwa terdapat hubungan yang signifikan antara gangguan pemusatan perhatian dan hiperaktifitas dengan prestasi belajar siswa kelas 1 Sekolah Dasar (SD).

Simtom ADHD mulai terlihat sebelum usia 12 tahun (APA, 2013). Simptom yang muncul harus ada setidaknya dalam dua setting yaitu sekolah dan rumah, serta harus ada bukti yang jelas adanya gangguan terhadap fungsi akademik, sosial, ataupun pekerjaan (APA, 2013). Berdasarkan DSM-5, ADHD dibagi ke dalam tiga subtipe: (1) tipe inattention; (2) tipe hyperactive-impulsive; ataupun (3) tipe kombinasi antara inattention dan hyperactive-impulsive (APA 2013).

Penanganan yang digunakan untuk anak ADHD dapat menggunakan berbagai metode, seperti terapi perilaku, terapi nutrisi, farmakoterapi, terapi musik, terapi lumba-lumba, dan terapi bermain (Erinta \& Budiani, 2012). Meskipun pengobatan medis paling banyak digunakan untuk mengobati ADHD dengan tingkat severe, namun hal tersebut tidak terlalu efektif atau dapat diterima oleh anak yang telah terdiagnosa ataupun orang tuanya, serta efek samping yang dapat terjadi dari pengobatan medis (Baumeister et al., 2018).

Musik memiliki kapasitas untuk 
mengembangkan kesadaran individu tentang diri mereka sendiri dan lingkungan, memperkuat harga diri, memperluas keterampilan komunikasi verbal dan nonverbal, keterampilan sosial, dan kemampuan untuk mengekspresikan emosi, meningkatkan kemampuan untuk memperhatikan tugas, dan meningkatkan keterampilan menghafal (Canadian Association for Music Therapy, 2006). Dengan diberikannya terapi musik pada anak ADHD, dapat membuat anak menjadi lebih tenang sehingga anak dapat meningkatkan kemampuannya untuk memperhatikan tugas. Menurut Wigram et al. (dalam Djohan, 2006), bila elemen dalam musik stabil dan dapat diprediksi, maka subjek cenderung merasa lebih rileks. Akan tetapi bila elemen dalam musik bervariasi di setiap saat dan subjek merasa ada perubahan yang tiba-tiba, maka tingkat rangsangan akan menjadi lebih tinggi karena adanya stimulasi. Dalam beberapa literatur juga menunjukkan bahwa penggunaan musik dapat meningkatkan memori dan perhatian seseorang (Canadian Association for Music Therapy, 2006).

Menurut Djohan (2006) apabila seseorang mendengarkan sebuah melodi, berarti ia mengaktifkan temporal hemisfer kanan (auditori) yang akan berhubungan dengan hemisfer kiri (bahasa). Bila hanya mendengarkan nada saja, maka akan melibatkan memori jangka pendek (short term memory) dan akan terjadi aktivasi yang khusus dari sistem kortikal auditori hemisfer kanan. Ketika seseorang mendengarkan musik, otak memproses musik tersebut di dalam auditory cortex melalui thalamus (Weinberger, 2004). Thalamus itu sendiri berada di bawah lapisan setelah cerebral cortex, yang memiliki fungsi untuk memusatkan perhatian pada stimulus sensorik tertentu (Kalat, 2004). Adapun salah satu bentuk dari stimulus sensori yaitu audio dalam hal ini musik. Oleh karena itu musik dapat dijadikan sebagai salah satu terapi musik untuk anak ADHD.

Metode intervensi dengan menggunakan musik, efektif digunakan untuk menurunkan perilaku hiperaktif pada anak ADHD (Rusmawati \& Dewi, 2011). Hal tersebut dikarenakan kerja terapi musik adalah dengan menggunakan musik untuk sebuah kesenangan, tetapi secara spesial dapat mengubah cara kerja otak yang 'lama' ke cara kerja yang baru dan tidak akan mengganggu (Berger dalam Rusmawati, 2011). Terapi musik merupakan salah satu jenis terapi yang dapat digunakan untuk mental illness (Rusmawati, Widyorini \& Sumijati, 2012). Hooper (2001) menjelaskan bahwa musik merupakan salah satu bentuk terapeutik. Terapi musik juga dapat meningkatkan rentang perhatian, meningkatkan motivasi, menenangkan orang yang gelisah, dan juga dapat digunakan untuk menguatkan perilaku atau respon yang disukai (Barrow-Moore, 2007).

Menurut Jackson dan Rickson (dalam Zhang, et al., 2012 pemberian intervensi musik dapat menurunkan frekuensi perilaku maladaptif dari ADHD dan dapat mengurangi kondisi gangguan lainnya seperti gangguan belajar, ODD, $\mathrm{CD}$, depresi, tic disorder, dan adjustment disorder. Oleh karena itu Rickson (dalam Zhang, et al., 2012) menyatakan bahwa pemberian intervensi musik dapat berkontribusi pada pengurangan gejala ADHD di kelas dan peningkatan dalam berbagai bidang perkembangan lainnya.

Berdasarkan penelitian sebelumnya yang dilakukan oleh Chandra (2007) dan Rusmawati et al. (2012), terapi musik dapat dikatakan cukup efektif untuk memodifikasi perilaku anak berkebutuhan. Menurut Chandra (2007), 
terapi musik dapat mengurangi perilaku repetitif pada anak autis. Hal tersebut disebabkan oleh pengaruh musik yang membuat anak menjadi lebih rileks. Dengan masuknya suara musik ke telinga dalam bentuk gelombang elektromagnetik dan diteruskan ke otak yaitu pada lobus temporalis, maka pada saat yang bersamaan zat kimia yang ada dalam otak yang disebut sebagai endorfin juga ikut dilepaskan sehingga membuat anak menjadi lebih rileks (Chandra, 2007). Semakin rileks kerja otot, maka semakin nyaman dan rileks anak tersebut sehingga perilaku repetitif anak autis menjadi berkurang dan dapat meningkatkan kemampuan belajar anak di sekolah (Chandra, 2007).

Dengan demikian, intervensi pada penelitian ini merupakan pengembangan dari penelitian sebelumnya yang dilakukan oleh Rusmawati et al. (2012) untuk menangani kesulitan berperilaku anak ADHD subtipe hiperaktif pada siswa Sekolah Dasar (SD). Hal tersebut dikarenakan adanya keterbatasan dalam penelitian sebelumnya, apakah dampak dari terapi musik dan/atau terapi gerak yang berpengaruh terhadap penurunan perilaku hiperaktif pada anak ADHD. Oleh karena itu peneliti bermaksud mengadaptasi musik instrumental yang digunakan dalam terapi musik tersebut tanpa diberikannya terapi gerak pada anak ADHD yang telah terdiagnosis ADHD subtipe hiperaktif. Intervensi pada penelitian ini menggunakan terapi musik untuk memodifikasi perilaku (behaviour modification) hiperaktif anak ADHD.

Tujuan dari penelitian yaitu untuk mengetahui pengaruh dari pemberian intervensi musik terhadap perilaku hiperaktif anak ADHD (Attention-Deficit Hyperactive Disorder) di mana perubahan tersebut dapat diamati melalui penurunan perilaku hyperactive.
Penelitian ini diharapkan dapat memberikan manfaat secara teoretis dalam ilmu psikologi, khususnya dalam melakukan intervensi dengan media musik pada anak Attention-Deficit Hyperactive Disorder (ADHD). Adapun manfaat praktis dari penelitian ini yakni dapat menurunkan perilaku hyperactive pada anak Attention-Deficit Hyperactive Disorder (ADHD), sehingga diharapkan dapat meningkatkan performa belajar anak di sekolah.

\section{Metode}

Variabel yang digunakan dalam penelitian ini adalah hiperaktivitas pada anak ADHD sebagai variabel tergantung, dan terapi musik sebagai variabel bebas. Adapun definisi operasional dari hiperaktivitas pada anak ADHD merupakan suatu hambatan dalam kontrol diri, pemusatan perhatian, serta hiperaktivitas/impulsivitas pada anakanak, sehingga mereka mengalami kesulitan mengontrol perilaku dalam situasi formal. Perilaku tersebut biasanya ditunjukkan dengan perilaku menggoyang-goyangkan kursi dan/atau badan saat diharapkan sedang duduk tenang, keluar bangku dan berjalan-jalan di kelas tanpa tujuan yang pasti, mengetuk-ngetukkan tangan atau kaki saat sedang duduk, memanjat-manjat dalam situasi saat anak diharapkan untuk duduk tenang, mengalami kesulitan untuk terlibat dalam kegiatan dengan tenang, menjawab pertanyaan sebelum orang lain menyelesaikan pertanyaannya, kesulitan menunggu giliran, serta menginterupsi atau menyerobot orang lain sehingga hal tersebut dirasa cukup mengganggu proses pembelajaran anak di sekolah. Variabel bebas dalam penelitian ini yaitu musik. Musik merupakan sebuah alunan yang dinamis dalam bentuk instrumental Heykens 
Serenade dan Toseli Serenade yang diperdengarkan kepada anak selama 30 menit.

Partisipan dalam penelitian ini adalah anak usia 8-9 tahun yang telah terdiagnosa ADHD oleh dokter dan/atau psikolog, serta belum pernah mengikuti program intervensi musik. Penelitian ini menggunakan rancangan single-case experimental design. Pada desain penelitian ini, tidak terdapat kelompok kontrol karena penelitian ini bisa disebut juga dengan "one experimental design" atau "small-n research designs". Rancangan desain penelitian yang digunakan yaitu dengan metode multiple baseline. Setelah

Tabel 1.

Deskripsi Partisipan Penelitian memberikan penilaian pada fenomena yang sama. Analisis data dalam penelitian ini menggunakan teknik analisis visual grafik atau disebut dengan visual inspection. Data akan dianalisis menggunakan perbandingan skor partisipan pada fase baseline I (A1), fase intervensi (B), dan fase baseline 2 (A2).

\section{Hasil}

Hasil penelitian ini terdiri dari analisis kuantitatif dan analisis deskriptif dari hasil skor partisipan pada fase baseline I (A1), fase intervensi (B), dan fase baseline 2 (A2). Tabel 1 menunjukkan deskripsi

\begin{tabular}{lc}
\hline Nama (inisial) & RG \\
\hline Tanggal Lahir & Mei 2010 \\
Usia & 8 tahun 6 bulan \\
Jenis kelamin & Laki-laki \\
Anak ke- & 1 dari 1 bersaudara \\
Pendidikan & Siswa kelas II di Sekolah Inklusi Yogyakarta \\
\hline
\end{tabular}

data baseline mencapai trend dan level stabil intervensi mulai diberikan kepada (variabel, kondisi, atau subjek) yang pertama. Penelitian ini menggunakan metode A-B-A dengan pemberian intervensi musik sebanyak 12 sesi/hari yang dilakukan selama 30 menit. Adapun instrumen penelitian yang digunakan yaitu behavioral checklist dengan proses pengamatan terhadap target perilaku hiperaktif anak ADHD selama 60 menit menggunakan alat bantu perekam video. Pengamatan dilakukan pada 3 tahapan yaitu fase baseline I (A1), fase intervensi, dan fase baseline II (A2). Analisis data pengukuran reliabilitas dalam penelitian ini yaitu menggunakan metode interobserver, yaitu sejauh mana taraf kekonsistenan para observer dalam partisipan penelitian.

RG telah terdiagnosis ADHD oleh psikolog sejak usia 2,5 tahun. Orang tua membawa RG ke Unit Konsultasi Psikologi UGM dan Tumbuh Kembang Sardjito, dan kemudian RG didiagnosis ADHD. Orang tua RG sudah mulai mencurigai bahwa adanya gangguan pada perkembangan pada RG yaitu sejak RG mengalami keterlambatan dalam perkembangannya. Seperti halnya melewati fase merangkak, cenderung berlari bukan berjalan, terlambat berbicara. Seusai melewati fase merangkak, ia langsung menuju fase merambat. Setelah pihak keluarga mengetahui bahwa RG mengalami ADHD, RG mulai mengikuti beberapa bentuk terapi.

Perilaku-perilaku yang ditampilkan 
RG baik di sekolah ataupun rumah yaitu sulit mempertahankan perhatian, mudah terganggu dengan stimulus dari luar, berbicara berlebihan saat jam pelajaran, menjawab pertanyaan sebelum orang lain menyelesaikan pertanyaannya, sulit menunggu giliran, dan menginterupsi atau menyerobot orang lain. Jika di dalam kelas, anak seringkali menggoyanggoyangkan kursinya pada saat sedang duduk. Ia juga seringkali meminta izin kepada guru untuk minum, namun selain itu ia akan melakukan kegiatan lainnya dan membutuhkan waktu yang lama untuk kembali ke tempat duduk. Pada saat jam pelajaran, RG sering mengangkat tangannya saat melihat teman-temannya yang lain juga ikut mengangkat tangan untuk menjawab pertanyaan yang diberikan oleh guru. Akan tetapi pada saat RG mendapatkan giliran untuk menjawab, seringkali RG tidak dapat menjawab pertanyaan guru dengan benar.

\section{Analisis kuantitatif partisipan RG}

Berdasarkan data pada grafik 1 dan tabel 2, dapat kecenderungan arah (trend) pada grafik terlihat menurun, yaitu dari kondisi partisipan RG sebelum diberikannya intervensi (baseline 1), selama proses intervensi berlangsung, dan kondisi setelah dilakukannya intervensi (baseline 2). Hal tersebut mengindikasikan bahwa dengan adanya pemberian intervensi musik dapat menurunkan perilaku hiperaktif anak ADHD. Hal tersebut dapat dilihat dari adanya perbedaan skor perubahan level antar fase yang mengalami penurunan.

$$
\text { Adapun tujuan utama }
$$

dilakukannya penelitian ini adalah untuk mengetahui efek pemberian intervensi musik terhadap penurunan perilaku hiperaktif pada anak ADHD. Oleh karena itu setelah adanya penjabaran secara umum mengenai proses pelaksanaan intervensi, grafik 2 menunjukkan efek perkembangan perilaku hiperaktif pada partisipan RG yaitu pada kondisi sebelum (baseline 1) dan setelah intervensi dilakukan (baseline 2).

Pelaksanaan pengambilan data pada baseline 1 (A1) dan baseline 2 (A2) dilakukan pada setting alami, yakni pada saat suasana proses pembelajaran di kelas. Grafik 2 merupakan gambaran hasil dari amatan perkembangan perilaku hiperaktif RG sebelum dan setelah diberikannya intervensi musik. Grafik di atas menggambarkan adanya kecenderungan arah (trend) yang menurun yaitu dari kondisi dimana partisipan sebelum diberikan intervensi (A1) dan setelah dilakukannya intervensi (A2). Adanya skor perubahan antar fase (A1) dan fase (A2) juga menunjukkan adanya penurunan sebesar 21 poin di

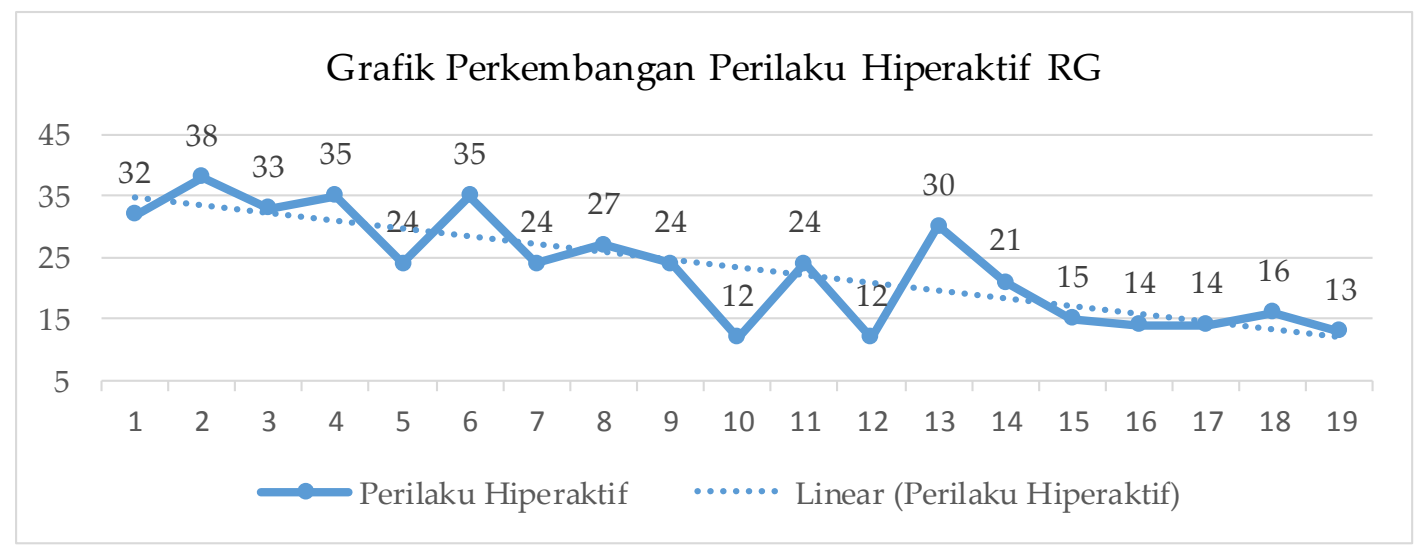

Grafik 1. Perkembangan perilaku hiperaktif partisipan RG 
Tabel.2

Analisis Visual Inspection Perilaku Hiperaktif pada Partisipan RG

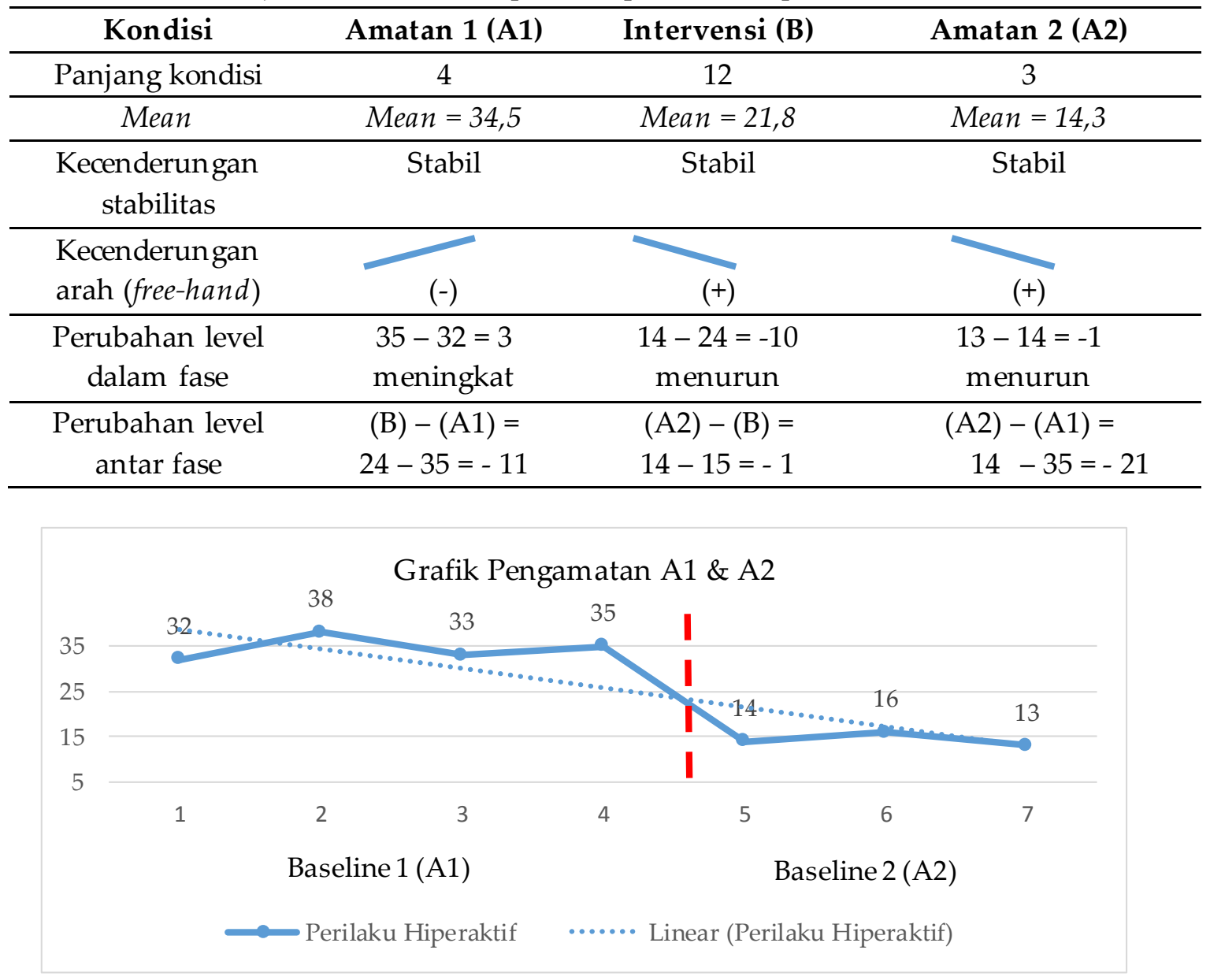

Grafik 2. Hasil pengamatan A1 dan A2 partisipan RG

mana fase baseline 2 (A2) lebih rendah jika dibandingkan dengan kondisi baseline 1 (A1). Hal ini mengindikasikan jika intervensi musik ini dapat menurunkan perilaku hiperaktif pada partisipan RG.

\section{Analisis deskriptif partisipan RG}

Berdasarkan hasil observasi secara keseluruhan, partisipan menunjukkan adanya penurunan pada perilaku hiperaktifnya. pengamatan terhadap perilaku hiperaktif partisipan selama penelitian ini berlangsung, partisipan dapat menikmati dan antusias dengan aktivitasnya. Partisipan terlihat lebih mudah diajak bekerjasama saat kegiatan berlangsung. Selain itu juga terlihat perubahan terhadap perilaku partisipan saat pembelajaran di kelas. Di saat partisipan RG sedang mengerjakan soal yang diberikan oleh guru, ia tampak lebih fokus saat mengerjakannya. Posisi duduk RG tampak lebih tenang dibandingkan jika ia duduk saat guru sedang menjelaskan di depan kelas. Partisipan RG dapat menyelesaikan soal yang diberikan oleh guru dengan rata-rata waktu selama 35 menit. $\mathrm{Di}$ saat mengerjakan tugas, partisipan RG lebih memilih untuk menghampiri gurunya dibandingkan mengangkat tangan dan menunggu giliran meskipun guru sedang menjelaskan ke siswa lainnya. Setiap kali selesai mengerjakan tugas, partisipan RG 
segera mengambil kotak yang berisi mainan lalu bermain sendiri. Permainan yang biasanya dipilih olehnya yaitu permainan balok.

\section{Diskusi}

Pemberian intervensi musik merupakan intervensi yang sedang berkembang sebagai sebuah intervensi sistematis dengan terapis yang membantu klien untuk meningkatkan kesehatan (Bruscia, 2014). Perkembangan terapi musik yang tergolong masih baru, tentunya tidak lepas dari berbagai perdebatan yang masih mempertanyakan efektivitas, standar prosedur, musik yang digunakan dan berbagai hal lain yang menjadi detail dalam terapi (Geraldina, 2017). Terapi musik adalah salah satu jenis terapi yang universal dan bisa diterima oleh semua orang karena tidak membutuhkan kerja otak yang berat untuk menginterpretasikan alunan musik (Geraldina, 2017).

Hasil penelitian menunjukkan bahwa adanya penurunan perilaku hiperaktif pada partisipan RG setelah program pemberian intervensi musik. Hal ini terlihat dari perubahan frekuensi dari sebelum dan setelah pemberian intervensi, yaitu pada kondisi baseline I (A1) dan kondisi setelah intervensi diberikan yaitu baseline II (A2). Menurut Sunanto, Takeuchi, \& Nakata (2005) untuk menganalisa suatu data single subject research design, maka perlu difokuskan pada: 1) level stabilitas; 2) kecenderungan arah (trend); 3) perubahan dalam fase; dan 4) perubahan antar fase. Pada partisipan RG memiliki level stabilitas yang stabil yaitu $100 \%$ pada fase baseline I (A1) dan $100 \%$ pada fase baseline II (A2). Level stabilitas dikatakan stabil jika lebih besar dari 80\% (Sunanto, Takeuchi, \& Nakata, 2005). Kecenderungan arah (trend) dari partisipan RG juga menurun (terlihat pada tabel. 2). Selain itu juga dapat dilihat dari rerata yang diperoleh pada fase baseline I (A1) dan fase baseline II (A2), dimana terjadi penurunan skor dari 34,5 menjadi 14,3. Hal tersebut juga dapat mengindikasikan bahwa terjadinya penurunan perilaku hiperaktif pada partisipan RG.

Dengan mendengarkan musik selama 30 menit selama 12 hari, terjadi penurunan perilaku hiperaktif pada partisipan RG. Menurut Rusmawati (2011) musik dapat berpengaruh langsung ke otak dan berakibat pada proses kerja tubuh. Pada anak-anak yang terlalu aktif, terapi musik yang diberikan, pada intinya harus bisa memuaskan emosi anak yang sering berlebihan. Aktivitas fisik anak akan tampak menurun sementara daya konsentrasinya meningkat (Rusmawati, 2011). Musik memiliki potensi untuk dapat meningkatkan kerja otak, minat, aktivitas, perilaku sosial dan belajar, mengarahkan ketegangan, mengatur perilaku, serta mengekspresikan emosi. Menurut Djohan (2006) keterampilan mengingat bagi beberapa siswa dapat lebih maksimal bila menggunakan strategi terapi musik. Hal tersebut dikarenakan dengan mengenali lagu dan irama secara langsung, dapat mengakomodasikan pengembangan keterampilan bahasa. Irama, lirik dan melodi memiliki keterkaitan yang kuat terhadap memori (Djohan, 2006).

Pada dasarnya, tujuan dari terapi musik itu sendiri yaitu untuk sebuah pencapaian yang positif (Bruscia, 2014). Menurut Berger (2002), musik secara langsung diproses melalui sistem limbik (amygdala, thalamus, cerebral hypothalamus, hippocampus). Melalui sistem pendengaran suara masuk ke dalam otak, memicu faktor emosional yang mendorong motivasi dan kemauan untuk 
membuat pilihan dan melakukan pola sensorik baru. Pada dasarnya musik adalah aktivitas whole brain, two brain, yang mendorong kognisi otak kiri dengan menggunakan otak kanan untuk merangsang belahan otak kiri sehingga dapat bekerja sama (Berger, 2002). Hal ini juga didukung oleh penelitian-penelitian sebelumnya yaitu terapi musik dapat menurunkan perilaku hiperaktif dan inatensi pada anak ADHD (Rusmawati, 2011; Yutapratama, 2016).

\section{Kesimpulan}

Berdasarkan hasil penelitian dapat disimpulkan bahwa program intervensi musik dapat memberikan pengaruh terhadap penurunan perilaku hiperaktivitas pada partisipan. Namun demikian perlu diperhatikan bahwa penelitian ini menggunakan metode single subject experimental design, di mana hasil dari partisipan tidak dapat digeneralisasikan.

Saran

Penelitian selanjutnya dapat melakukan penelitian dalam cakupan yang lebih luas, misalnya dengan menambahkan jumlah partisipan dari anak ADHD dan dapat diperluas dengan subtipe yang berbeda. Selain itu juga dapat menambahkan pengukuran terhadap metode yang digunakan untuk mengukur perilaku hiperaktif anak ADHD, yaitu dengan cara menambahkan intensitas dan durasi sebagai indikator pengukuran perilaku hiperaktif dalam pengukuran behavioral checklist.

Perlu adanya alokasi waktu dalam persiapan maupun pelaksanaan penelitian. Hal ini karena penelitian ini membutuhkan waktu yang panjang untuk mempersiapkan penelitian, dari pemilihan musik, memilih dan melatih terapis atau instruktur yang akan terlibat dalam pelaksanaan program, observer yang akan memberikan penilaian terhadap perilaku hiperaktif, serta pemberian waktu dari pihak sekolah yang memiliki keterbatasan dengan jadwal-jadwal yang telah ditetapkan oleh pihak sekolah.

\section{Daftar Pustaka}

American Psychiatric Association. (2013). Diagnostic and statistical manual of mental disorder (Edisi kelima). Washington, DC: American Psychiatric Association.

Barkley, R. A (2006). Attention-deficit hyperactivity disorder: A handbook for diagnosis and treatment (Edisi ketiga). New York: The Guilford Press.

Barrow-Moore, J. L. (2007). The effects of music therapy on the social behavior of children with autism. California State University San Marcos.

Baumeister, S. , Wolf, I., Holz, N., BoeckerSchlier, R., Adamo, N., Holtmann, M., Ruf, M., Banaschewski, T., Hohmann, S., Brandeis, D. (2018). Neurofeedback training effects on inhibitory brain activation in ADHD: A matter of learning. Neuroscience, 378, 89-99. doi: $\underline{10.1016 / j . n e u r o s c i e n c e .2016 .09 .025 ~}$

Berger, D. 2002. Music therapy, and the autistic child sensory integration. Philadelphia: Jessica Kingsley Publisher.

Bruscia, K. E. (2014). Defining music therapy (Edisi ketiga). USA: Barcelona Publishers.

Canadian Association for Music Therapy. (2006). Specific applications of musical techniques in music therapy. Diunduh dari http://www.musictherapy.ca/ methods.html

Chandra, A. (2007). Terapi musik untuk mengurangi perilaku repetitif pada anak autis. (Tesis master tidak dipublikasikan). Universitas Gadjah 
Mada, Yogyakarta.

Christina, Y. M. (2012). Perbandingan faktor risiko gangguan pemusatan perhatian pada anak di daerah pedesaan dan perkotaan di Kecamatan Cangkringan Kabupaten Sleman. (Tesis master tidak dipublikasikan). Universitas Gadjah Mada, Yogyakarta.

Djohan (2006). Terapi musik: Teori dan aplikasi. Yogyakarta: Percetakan Galangpress.

Erinta, D., dan Budiani, M. S. (2012). Efektivitas penerapan terapi permainan sosialisasi untuk menurunkan perilaku impulsif pada anak dengan Attention Deficit Hyperactivity Disorder (ADHD). Jurnal Psikologi Teori \& Terapan, 3(1), 67-78. doi: 10.26740/jptt.v3n1.p67-78

Geraldina, A. M. (2017). Terapi musik: Bebas budaya atau terikat budaya. Buletin Psikologi, 25(1), 45 - 53. doi: $\underline{10.22146 / \text { buletinpsikologi.27193 }}$

Hooper, J. (2001). Overcoming the problems of deinstitutionalisation: Using music activities to encourage interaction between four adults with a developmental disability. Music Therapy Perspectives, 19(2), 121-127. doi: $\underline{10.1093 / \mathrm{mtp} / 19.2 .121}$

Lalusu, R., Kaunang, T. M., Kandou, L. F. (2014). Hubungan gangguan pemusatan perhatian dan hiperaktivitas dengan prestasi belajar pada anak SD Kelas 1 di Kecamatan Wenang Kota Manado. Jurnal e-CliniC (eCl), 2(1), 1-5. doi: $\underline{10.35790 / \mathrm{ed} \cdot 2 \cdot 1.2014 .4080}$

Lee, D. H. (2005). Comorbid oppositional defiant or conduct disorder problems in children at high-risk for Attention Deficit Hyperactivity Disorder (ADHD): A comparison of emotional, psychosocial, and behavioral adjustment. Disertasi. University of Florida.

Kalat, J. W. (2004). Biological psychology
(Edisi kedelapan). Belmont, CA: Wadsworth Publishing.

Rahmi, I. \& Wimbarti S. (2018). Inhibition in ADHD and non-ADHD children ages 6-12 years. International Journal of Research Studies in Psychology, 7(1), 73-85. doi: 10.5861/ijrsp.2018.2008

Rusmawati, D., Dewi, E. K. (2011). Pengaruh terapi musik dan gerak terhadap kesulitan perilaku siswa sekolah dasar dengan gangguan ADHD. Jurnal Psikologi Universitas Diponegoro, $\quad$ 9(1). doi: 10.14710/jpu.9.1

Rusmawati, D., Widyorini, E., \& Sumijati V. S. (2012). Pengaruh terapi musik dan gerak terhadap penurunan hiperaktifitas anak yang mengalami Attention Deficit Hyperactivity Disorder (ADHD). Prediksi, Kajian Ilmiah Psikologi, 1(2), 213-217.

Sunanto, J., Takeuchi, K., \& Nakata, H. (2005). Pengantar penelitian dengan subjek tunggal. Criced University of Tsukuba. Diunduh dari http://earchive.criced.tsukuba.ac.jp/data/do c/pdf/2005/10/TEXT.685.pdf

Szatmari, P., Boyle, M., \& Offord, D. R. (1989). ADDH and conduct disorder: Degree of diagnostic overlap and differences among correlates. Journal of the American Academy of Child E Adolescent Psychiatry, 28(6), 865-872. doi: $\quad \underline{10.1097 / 00004583-198911000-}$ $\underline{00010}$

Weinberger, N. M. (2004). Music and the brain. Scientific American. 291(5), 8895.

Yutapratama, N. (2016). Pengaruh terapi musik instrumental dalam pembelajaran terhadap perilaku inatensi pada anak ADHD Kelas III di SDN Gejayan. Jurnal Widia Ortodidaktika, 5(11), 1146-1155.

Zhang, F., Liu, K., An, P., You, C., Teng, L., Liu, Q. (2012). Music therapy for Attention Deficit Hyperactivity 
TERAPI MUSIK, PERILAKU HIPERAKTIF, ADHD

Disorder (ADHD) in children and

Systematic Reviews, 8. Art. No.: CD010032. adolescents. Cochrane Database of 